\title{
PENGARUH IKLAN SABUN MANDI DI TELEVISI TERHADAP PERUBAHAN PERILAKU SISWA KELAS VII SLTP SULUH JAKARTA
}

\author{
Eko Purnomo \\ Dosen Universitas Indraprasta PGRI \\ haryowiguno@gmail.com
}

\begin{abstract}
ABSTRAK
Perkembangan iklan di media televisi Indonesia terbilang cukup pesat mengingat pertumbuhan media elektronik juga ikut merambah di indonesia, maka produsen iklan media televisi tidak mau ketinggalan dan ingin terus diterima di masyarakat. Dewasa ini, masyarakat khususnya di indonesia lebih pintar dalam memilih apa yang mereka butuhkan, oleh karena itu, para produsen berlomba-lomba melakukan kegiatan yang terbilang unik dan menarik agar tetap dihati konsumen. Perumusan masalah dalam penelitian ini adalah pengaruh tayangan iklan televisi sabun lifebuoy terhadap perubahan perilaku maka tujuan penelitian ini adalah, untuk melihat pengaruh tayangan iklan televisi terhadap perubahan perilaku Siswa kelas VII SLTP Suluh Jakarta.Kerangka teori yang digunakan dalam penelitian terdiri atas, Teori Stimuly organisme respon, social learning theory dan juga model Hierarchy of Effect sebagai landasan perbedaan pengaruh perubahan perilaku setiap individu-individu dalam melihat sesuatu yang menarik baginya. Penelitian ini bersifat daskriptif kuantitatif, yang merupakan bertujuan memamparkan situasi atau berbagai peristiwa, dan data didapat dari populasi yang merupakan Siswa SLTP Suluh sejumalah 56 responden, penarikan sample menggunakan proposional sampling yang merupakan bagian dari probability sampling. Berdasarkan hasil penelitian, responden Siswa kelas VII SLTP Suluh Jakarta yang cenderung ber jenis kelamin laki-laki (62,5\%), pengguna sabun kesehatan $(53,6 \%)$ yang mendapatkan uang jajan $\geq 300.000$ sebulan $(62.5 \%)$ bahwa pengaruh tayangan iklan televisi lifebuoy terhadap perubahan perilaku Murid SLTP Suluh Jakarta adalah pengaruh perubahan perilaku kuat rendah, dan berpengaruh sebesar $(52,5 \%)$.
\end{abstract}

Kata kunci: Pertumbuhan media elektronik, perubahan perilaku dan pengaruh iklan.

\begin{abstract}
The development of advertisement in Indonesian television media is quite fast considering the growth of electronic media also penetrated in Indonesia, the television media advertising producers do not want to miss and want to continue to be accepted in the community. Today, people especially in Indonesia are smarter in choosing what they need, therefore, the producers are competing to perform activities that are unique and interesting to keep consumers hearted.The formulation of the problem in this research is the influence of television advertisement advertisement of lifebuoy soap to behavior change hence the purpose of this research is, to see the influence of television advertisement advertisement to the behavior change of Grade VII student of SLTP Suluh Jakarta. The theoretical framework used in the study consists of Stimulus Theory, response organism, social learning theory and also the Hierarchy of Effect model as the basis of the difference in the effect of behavior
\end{abstract}


change of each individual in seeing something that interest him. This research is quantitative daskriptif, which aims to spread the situation or various events, and the data obtained from the population that is the students of SLTP Suluh sejumalah 56 respondents, sampling using proportional sampling which is part of probability sampling. Based on the result of the research, the respondents of Grade VII students of SLTP Suluh Jakarta who tend to have male gender (62.5\%), health soap users (53.6\%) who get pocket money $\geq 300.000$ per month $(62.5 \%)$ that influence ad impressions television lifebuoy to behavior change Student of SLTP Suluh Jakarta is the influence of change of behavior strongly low, and influential equal to $(52,5 \%)$.

Key words: Growth of electronic media, behavior change and advertising influence.

\section{A. Pendahuluan}

Periklanan saat ini sudah berkembang sangat pesat, dan bukan suatu hal yang asing buat kita untuk menjual atau menawarkan suatu produk dan jasa, terutama dalam proses membangun merek atau branding. Kegiatan periklanan yang efektif dipandang mampu mempengaruhi kecenderungan mengkonsumsi dalam masyarakat. Periklanan yang efektif juga akan mengubah pengetahuan publik mengenai ketersediaan dan karakteristik sebuah produk. Periklanan dipandang sebagai media yang paling lazim digunakan suatu perusahaan khususnya produk konsumsi untuk mengarahkan komunikasi yang persuasif pada konsumen. Iklan ditujukan untuk mempengaruhi perasaan, pengetahuan, makna, kepercayaan, sikap, dan citra konsumen yang berkaitan dengan suatu produk atau merek. Tujuan ini bermuara pada upaya mempengaruhi perilaku konsumen dalam membeli.

Meskipun tidak secara langsung berdampak pada pembelian, iklan menjadi sarana untuk membantu pemasaran yang efektif dalam menjalin komunikasi antara perusahaan dan konsumen, dan sebagai upaya perusahaan dalam menghadapi pesaing. Kemampuan ini muncul karena adanya suatu produk yang dihasilkan suatu perusahaan. Bagaimanapun bagusnya suatu produk, jika dirahasiakan dari konsumen maka tidak ada gunanya. Konsumen yang tidak mengetahui keberadaan suatu produk tidak akan menghargai produk tersebut.

Iklan adalah salah satu cara memperkenalkan sebuah produk yang umum dilakukan oleh perusahaan. Bahkan kegiatan iklan dianggap sangat penting jika ingin produknya sukses di pasaran. Tak heran setiap tahun, bahkan setiap launching produk baru, perusahaan menghabiskan ratusan juta bahkan miliaran rupiah untuk pengeluaran biaya iklan. Kondisi persaingan yang semakin ketat membuat biaya ini bertambah setiap tahunnya. Perusahaan berlomba-lomba membuat iklan untuk membangun posisi yang menguntungkan di pasar. Seiring pertumbuhan ekonomi, iklan menjadi sangat penting karena konsumen potensial akan memperhatikan iklan dari produk yang ia akan beli. Fungsi iklan selain sebagai promosi juga berfungsi menginformasikan suatu produk atau jasa perusahaan dan sebagai media untuk mengingatkan konsumen terhadap suatu produk atau jasa.

Menurut Ellen Nouuborne, Iklan juga sebagai bentuk presentasi non-pribadi dan promosi gagasan, barang, atau jasa, oleh sponsor tertentu yang harus dibayar. Iklan juga merupakan cara yang berbiaya efektif guna menyebarkan pesan, entah untuk membangun brand image atau untuk mendidik orang. Dan menurut Rudy harjanto di buku nya, iklan juga dapat sebagai pesan komunikasi pemasran atau 
publik tentang sesuatu produk yang di sampaikan melalui sesuatu media, di biayai oleh pemerkasa yang di kenal, serta di tujukan kepada sebagian atau seluruh masyarakat.

Seiring perkembangan jaman serta kemajuan teknologi maka iklan pun turut beradaptasi. Dari yang tujuannya sebagai media promosi hingga menjadi media pembelajaran. Iklan yang dimaksudkan sebagai media pembelajaran di sini bukanlah iklan-iklan layanan masyarakat, namun iklan suatu produk komersial. Sekarang suatu produk komersial dapat mengiklankan produknya bukan dengan cara mengangkat keunggulan produk tersebut dalam iklannya, namun bisa saja dengan mengangkat masalah atau isu yang berkaitan dengan produk tersebut. Beberapa produk bahkan menjadikan isu tersebut sebagai pokok pesan utama dalam cara berpromosinya.

Beberapa iklan televisi yang mengangkat isu sebagai pesan dalam berpromosi nya adalah pepsodent yang mengangkat isu "penting nya sikat gigi di malam hari" dan iklan aqua yang mengangkat isu "1 liter untuk 10 liter" Pada iklan produk tersebut, informasi mengenai keunggulan produk terselip dengan manis diantara pesan sosial yang dihadirkan sebagai inti pesan utamanya. Iklan-iklan tersebut memberikan gambaran nyata bahwa sebuah produk tidak selalu harus diangkat melalui kulaitas produk untuk pesan beriklannya namun cukup dengan mengangkat isu yang mengarah kepada kebiasaan konsumen terhadap produk yang hendak diiklankannya. Saat ini saya ingin mengangkat sebuah iklan dengan pendekatan yang sama untuk dianalisa, yaitu: sabun lifebouy yang mengangkat isu dalam iklan nya "Pentingnya mencuci tangan dengan sabun sebelum beraktifitas" dalam pesan beriklannya.

Saat ini sabun lifebouy sedang gencar-gencar nya berkampanye "penting nya mencuci tangan" sebagai pesan berpromosinya. Dalam kampanye tersebut lifebouy menciptakan sosok ayah dan seorang anak laki-lakinya yang sedang bersekolah, dan sang ayah pun sedang menunggu anak nya yang sedang belajar, kedua sosok tersebut digambarkan secara riang di pertengahan iklan, dan mudah dikenali hanya dalam beberapa kali melihat iklan televisinya.

Dalam iklan televisi tersebut sang ayah mengajarkan pentingnya menjaga kesehatan dengan menggunakan sabun, baik itu untuk mandi, mencuci tangan ataupun setelah buang air besar atau kecil, kepada anaknya, Sang anak yang awal nya kurang menjaga kesehatan dengan jarang mencuci tangan, akhir nya terkena penyakit flu dan mengakibatkan bersin-bersin, teman sebangku nya pun memberi sebuah kertas kepada sang anak tersebut yang isi nya 5 resep dokter kecil lifebouy, Anak yang memberi resep tersebut mengacungkan ibu jari nya kepada sang ayah anak tersebut, Dan di situ lah sang ayah memberikan 5 resep dokter kecil lifebouy tersebut dengan bernyanyi, yang isi nya penting nya menggunakan sabun lifebouy saat mandi, mencuci tangan baik pada pagi siang dan malam sebelum makan, dan setelah buang air besar atau pun kecil,Kegembiraan ditampilkan dalam iklan televisi tersebut melalui cara si ayah yang bernyanyi sambil mengajari anaknya tersebut. Lalu di ikuti oleh beberapa anak sekolah dasar termaksud anak dari sang ayah tersebut, Pendekatan dengan kegembiraan seperti itu dirasa bisa menyampaikan pesan lebih cepat dan di nilai lebih efektif dibandingkan pendekatan lainnya. 
Di iklan tersebut tidak terlalu di tonjolkan kelebihan pada produk lifebouy, bahkan pada saat memberi lima resep dokter kecil tersebut hanya menunjukan tiga kali produk sabun lifebouy dan hanya menunjukan beberapa detik saja produknya. Di sinilah nampak kekuatan dari isu yang diangkat oleh lifebouy. Dengan sedikit menampilkan produknya namun isu yang disampaikan sudah cukup untuk menggambarkan kualitas dan manfaat sabun lifebouy sebagai sabun kesehatan. Isu yang dikomunikasikan dengan sabun kesehatan terutama mencuci tangan identik dengan produk lifebouy. Tidak berlebihan jika saya menyebut iklan televisi tersebut lebih seperti iklan layanan masyarakat daripada iklan produk.

Isu yang ditampilkan dalam iklan televisi ini, yaitu: "Pentingnya mencuci tangan" sangatlah menjadi penting untuk diangkat mengingat fakta yang terjadi di kehidupan sehari-hari. Sampai sekarang kebiasaan mencuci tangan sebelum melakukan kegiatan, salah satu nya mencuci tangan sebelum makan, pagi siang dan malam belum menjadi kewajiban bagi masyarakat khususnya masyarakat Indonesia.

Mencuci tangan sebelum beraktivitas khusus nya sebelum makan belum menjadi kebiasaan masyarakat indonesia terutama di kalangan anak-anak, Sebelum kita makan, cuci tangan dahulu, jagalah kebersihan agar sehat selalu. Banyakbanyak makan jangan ada sisa, ayo kita makan bersama, Petikan lagu yang biasa dinyanyikan siswa taman kanak-kanak ketika hendak mulai memakan makanan mereka yang dibawa dari rumah mengisyaratkan bahwa cuci tangan itu sangat penting untuk menjaga kebersihan dan supaya badan sehat selalu.

Perilaku hidup sehat yang sederhana seperti mencuci tangan dengan sabun pun menurut World Health Organization (WHO) merupakan salah satu cara untuk meningkatkan kesadaran masyarakat tentang pemeliharaan kesehatan pribadi dan pentingnya berperilaku hidup bersih dan sehat. Ia juga berharap kampanye mencuci tangan dengan sabun sekaligus dapat dimanfaatkan sebagai momentum untuk memasyarakatkan perilaku hidup sehat, karena untuk membuat sesuatu yang besar kadang "kita" memang harus memulainya dari hal-hal kecil. Tidak salah memang jika para ibu selalu meminta agar selalu membersihkan tangan, makanan sayuran dan tidur dengan teratur. Menurut sejumlah dokter dan ahli nutrisi kebiasaan baik itu bisa menghindarkan seseorang dari penyakit flu. Menurut $\mathrm{Dr} R$ Michael Gallagher, kebiasaan itu setidaknya bisa menjadi hal yang terbaik untuk kesehatan seseorang. (SUMBER : Artikel Kesehatan)

Pertanyaan lalu timbul dari cara beriklan dengan metode menonjolkan isu pesan pada iklan. Bagaimana pemaknaan dari khalayak terhadap cara beriklan seperti yang di jabarkan di atas. Apakah dengan pendekatan seperti itu maka image sabun lifebouy akan menjadi lebih kuat sebagai sabun pencuci tangan atau hanya isu tentang kebiasaan mengunakan sabun yang utama nya sebelum makan akan menjadi lebih kuat. Lalu apakah iklan dapat menjadi media pembelajaran baru yang dapat membentuk kebiasaan individu maupun kelompok terutama pada anak-anak, dalam hal ini kebiasaan mencuci tangan dengan menggunakan sabun, Pertanyaanpertanyaan tersebut yang coba dijawab melalui karya ilmiah yang akan saya tulis ini. Karya ilmiah ini akan disusun menggunakan pendekatan penelitian kuntitatif serta iklan televisi 5 resep dokter kecil lifebouy versi "dik daong" sebagai bahan kajian penelitian. peneliti berharap karya ilmiah berjudul "pengaruh tayangan iklan lifebouy 5 resep dokter kecil versi "Dik-Doang ditelevisi tehadap perubahan 
perilaku murid SLTPN 240 Jakarta yang akan peneliti teliti ini dapat berguna, khususnya untuk perkembangan periklanan di Indonesia.

\section{B.. Hakikat Komunikasi}

Menurut Tubbs dan Sylvia Moss : 2005 yang di kutip oleh Ruddy Harjanto mendefinisikan komunikasi adalah sebagai proses penciptaan makna antara dua orang (komunikator 1 dengan komunikator 2) atau lebih. Menurut Taylor (1993) yang di kutip oleh Untung Sujianto dan Tatik Indirawati komunikasi adalah proses pertukaran informasi atau proses yang menimbulkan meneruskan makna atau arti, berarti dalam komunikasi terjadi penambahan pengertian antara pemberi informasi dan penerima informasi sehingga mendapatkan pengetahuan. Sedangkan menurut Engel, "Warshaw dan Kinner : 1994 di buku Ruddy Harjanto" komunikasi di bagi tiga unsur yaitu bersifat simbolis, kesengajaan dan transaksional :

1) Komunikasi bersifat simbolis : Penyampaian simbol-simbol yang di buat da di pergunakan agar membuat pihak lain berfokus pada objek atau orang yang di presentasikan oleh simbol tersebut.

2) Komunikasi bersifat kesengajaan : Ada nya upaya yang di lakukan dengan sengaja melalui pertimbangan yang bertujuan untuk menimbulkan tanggapan yang diinginkan.

3) Komunikasi bersifat transaksional : berbagai pesan saling di pertukarkan dengan maksud untuk memperoleh tanggapan secara timbal balik sesuai motivasi semua pihak yang berpartisipasi.

Selain itu komunikasi juga bersifat tetap, Ia tidak dapat ditarik kembali, hal ini merupakan bagian dari komunikasi sebagai suatu proses yang selalu berubah. komunikasi adalah "pertukaran informasi antara dua orang atau lebih pertukaran informasi. Dari pendapat tersebut, komunikasi merupakan proses pertukaran informasi atau yang memungkinkan interaksi antara dua orang atau lebih, yang di dalamnya terdapat kegiatan mengirim atau memberi, menerima dan menanggapi (umpan balik) pesan-pesan tersebut. Dalam proses komunikasi melibatkan tiga unsur, yaitu :

1) Pengirim (sender)

2) Media Komunikasi

3) Penerima (receiver)

Pengirim artinya orang yang mengambil inisiatif untuk melakukan tindakan komunikasi dan mengirimkan pesan kepada penerima, sedangkan penerima adalah orang yang menjadi sasaran penyampaian pesan komunikasi. Komunikasi dapat berupa verbal, yang berupa kata-kata lisan atau tulisan. Komunikasi non verbal, yang diungkapkan dengan tindakan, gerak tubuh ekspresi wajah, musik ataupun gambar. Lasswell mengatakan bahwa cara yang baik untuk menjelaskan komunikasi ialah menjawab pertanyaan sebagai berikut. :

Who Say What in What Channel To Whom With What Effect?
$\begin{array}{ll}\text { Who } & \text { : Sumber (komunikator) } \\ \text { Say What } & : \text { Pesan atau informasi } \\ \text { In What Channel } & : \text { Media apa yang digunakan } \\ \text { To Whom } & : \text { Komunikan atau khalayak sasaran }\end{array}$


With What Effect : Tujuan dari iklan yang dibuat, perubahan yang terjadi sebagai akibat dari pesan yang diterima seseorang dapat berupa perubahan sikap prilaku.

Jadi berdasarkan paradigma Laswell, definisi komunikasi adalah proses penyampaian pesan komunikator kepada komunikan (si penerima pesan) melalui media yang menimbulkan pengaruh tertentu Definisi komunikasi menurut Hovland, Janis dan Kelly (1953) adalah suatu proses yang terjadi antara satu orang dengan orang lain yang bertujuan untuk mengubah atau membentuk perilaku orang lainnya yang sasaran komunikasi.

Komunikasi merupakan suatu proses dimana serangkaian tindakan atau peristiwa yang terjadi biasanya berkaitan satu sama lain, dan proses komunikasi tersebut tidak akan statis, melainkan dinamis yang nantinya akan mengalami suatu perubahan yang berani dan berlangsung secara terus menerus. Komunikasi akan berjalan dengan efektif apabila orang yang mengirimkan pesan dalam hal ini komunikator, dengan orang yang menerima pesan dalam hal ini komunikan memiliki persamaan dengan kerangka berpikir atau pengetahuan. Hal ini berarti dalam menghasilkan komunikasi yang efektif harus ada kesamaan makna antara komunikator dan komunikan sehingga apa yang menjadi tujuan komunikasi itu sendiri yaitu perubahan sikap dan perilaku dapat terjadi.

Proses komunikasi terdiri dari dua cara yaitu proses komunikasi primer dan proses komunikasi sekunder. Proses komunikasi secara primer yaitu proses penyampaian pikiran dan perasaan komunikator kepada komunikan dengan menggunakan simbol sebagai media. Proses komunikasi sekunder yaitu proses penyampaian pesan oleh komunikator kepada komunikan dengan menggunakan alat atau sarana media kedua setelah memakai lambing sebagai media pertama.

Dapat diperoleh kesimpulan bahwa komunikasi merupakan proses penyampaian pesan atau rangsangan dalam bentuk verbal dari komunikator kepada komunikan melalui media tertentu untuk menghasilkan pengaruh tertentu. Dengan demikian proses komunikasi memiliki unsur-unsur utama, antara lain :

a. Komunikator

Komunikator adalah seseorang atau sekelompok orang yang menyampaikan pikirannya atau perasaannya kepada orang lain.

b. Pesan

Pesan sebagai terjemahan dari bahasa asing message adalah lambang bermakna, yakni lambang yang membawakan pikiran atau perasaan komunikator

c. Media

Media adalah sarana untuk menyalurkan pesan-pesan yang disampaikan oleh komunikator kepada komunikan.

d. Komunikan

Komunikan adalah seseorang atau sejumlah orang yang menjadi sasaran komunikator ketika ia menyampaikan pesannya.

e. Efek

Efek adalah tanggapan, respons atau reaksi dari komunikan ketika ia atau mereka menerima pesan dari komunikator. Jadi efek adalah akibat dari proses komunikasi." 
Komunikasi ditujukan untuk menumbuhkan sosial yang baik. Dengan melakukan komunikasi maka diharapkan dapat mengurangi kesalahpahaman antara seseorang dengan orang lain, kelompok maupun golongan tertentu. Komunikasi berperan dalam mengirim informasi dari pengertian komunikator kepada komunikan berupa ide, fakta, pemikiran, serta perasaan. Selain itu manusia melakukan komunikasi untuk mempengaruhi orang lain atau dapat dikatakan bahwa komunikasi bersifat persuasif sehingga orang lain bertindak seperti atas kehendak sendiri.

Di dalam peranan komunikasi itu sendiri mencukupi kebutuhan masyarakat akan barang dan jasa dalam mempromosikan suatu produk sangatlah penting. Komunikasi juga diperlukan untuk menginformasikan product knowledge suatu brand terhadap masyarakat. Begitu pula fungsi media massa bagi dunia usaha dalam rangka menyebar maupun mempublikasikan suatu produk memiliki konstribusi yang besar. Untuk itulah dalam memenuhi arus informasi yang serba cepat, perlu dipergunakan periklanan melalui media massa, dalam hal ini televisi.

\section{Bentuk komunikasi}

Berdasarkan lingkup ilmu komunikasi ditinjau dari bentuknya, maka terdapat empat bentuk komunikasi, yaitu :

a) Komunikasi Kelompok Kecil (Small Group Comunication) adalah komunikasi yang terdiri lebih dari tiga orang, misalnya kuliah, seminar, dan diskusi panel.

b) Komunikasi Kelompok Besar adalah komunikasi yang berlangsung pada kelompok besar, misalnya rapat raksasa atau kampanye.

c) Komunikasi Massa adalah komunikasi masa modern dengan media massa sebagai saluran, misalnya radio, televisi, dan majalah.

d) Komunikasi Media adalah komunikasi dengan menggunakan alat seperti surat, telepon, pamflet, poster,dan spanduk.

Proses Komunikasi :

1. Komunikator (sender)

Yang mempunyai maksud berkomunikasi dengan orang lain mengirimkan suatu pesan kepada orang yang dimaksud. Pesan yang disampaikan bisa berupa informasi dalam bentuk bahasa ataupun lewat simbol-simbol yang dimengerti kedua pihak.

2. Pesan (message)

Pesan itu disampaikan atau dibawa melalui suatu media atau saluran baik secara langsung maupun tidak langsung. Contohnya berbicara langsung melalui telephone, surat, e-mail atau media lainnya.

3. Komunikan (receiver)

Menerima pesan yang disampaikan dan menerjemahkan isi pesan yang diterimanya ke dalam bahasa yang dimengerti kedua pihak.

4. Komunikan (receiver)

Memberikan umpan balik (feedback) atau tanggapan atas pesan yang dikirimkan kepadanya, apakah dia mengerti atau memahami pesan yang dimaksud oleh si pengirim. 


\section{Fungsi Komunikasi}

a. Menyampaikan informasi

Pengumpulan, penyimpanan, pemrosesan, penyebaran berita, data, gambar, fakta dan pesan, opini dan komentar yang dibutuhkan agar orang dapat mengerti dan bereaksi secara jelas terhadap kondisi internasional, lingkungan, dan orang lain, dan agar dapat mengambil keputusan yang tepat.

b. Mendidik

Pengalihan ilmu pengetahuan sehingga mendorong perkembangan intelektual, pembentukan watak, dan pendidikan keterampilan serta kemahiran yang diperlukan pada semua bidang kehidupan.

c. Menghibur

Penyebarluasan sinyal, simbol, suara dan citra (image) dari drama, tari, kesenian, kesusastraan, musik, komedi, olah raga, permainan, dan sebagainya untuk rekreasi dan kesenangan kelompok dan individu.

d. Mempengaruhi"

Agar orang lain bersedia menerima suatu paham atau keyakinan, melakukan perbuatan atau kegiatan, dan lain lain.

Dari uraian di atas, dapat disimpulkan bahwa komunikasi merupakan proses penyampaian suatu pesan dari suatu sumber berita kepada pihak penerima. Pentingnya komunikasi bagi manusia tidaklah dapat dipungkiri, karena dengan berkomunikasi manusia dapat berhubungan satu sama lain, selain itu komunikasi juga merupakan aktivitas dasar manusia.

Tujuan komunikasi pada hakekatnya adalah mengubah sikap (to change the attitude), mengubah opini atau pandangan (to change behaviour). Komunikasi yang efektif adalah komunikasi yang menimbulkan efek tertentu sesuai dengan tujuan komunikasi. Menurut Schramm dam Robert yang dikutip oleh Jalaluddin Rakhmat, beranggapan bahwa "efek hanya perubahan perilaku manusia yang setelah diterpa pesan media massa, karena fokusnya pesan maka efek haruslah berkaitan dengan pesan yang disampaikan media massa.“

\section{Komunikasi Massa}

Dikarenakan oleh isi dan judul yang berkaitan dengan penelitian ini, peneliti akan menjelaskan lebih dalam mengenai komunikasi massa karena iklan televisi merupakan bagian dari komunikasi massa.

Istilah komunikasi massa diadopsi dari istilah bahasa Inggris, mass communication, sebagai kependekan dari mass media communication (komunikasi media massa). Artinya, komunikasi yang menggunakan media massa atau komunikasi mass mediated. Istilah mass communications atau communications diartikan sebagai salurannya, yaitu media massa (mass media) sebagai kependekan dari media mass of communication

Komunikasi massa merupakan suatu proses dimana komunikatorkomunikator menggunakan media untuk menyebarkan pesan-pesan secara luas dan secara terus menerus menciptakan makna-makna yang diharapkan dapat mempengaruhi khalayak yang besar dan berbeda-beda dengan melalui berbagai cara.

Menurut De Fluer dan Dennis, komunikasi massa adalah suatu proses dimana komunikasi menggunakan media untuk menyebarkan pesan-pesan secara 
luas dan terus-menerus menciptakan makna-makna yang diharapkan dapat mempengaruhi khalayak yang besar dan berbeda-beda melalui berbagai cara, komunikasi massa menyiarkan informasi, sikap dan gagasan kepada komunikan yang beragam dalam jumlah yang banyak dengan menggunakan media meliputi surat kabar, majalah, televisi, radio dan film.

\section{Fungsi Komunikasi Massa}

Sedangkan fungsi komunikasi massa terhadap individu menurut Samuel. L. Becker adalah sebagai berikut:

1) Pengawas dan pencarian informasi

2) Mengembangkan konsep diri

3) Fasilitasi dalam hubungan sosial

4) Substitusi dalam hubungan sosial

5) Membantu melegakan emosi

6) Sarana pelarian dari ketegangan dan keterasingan

7) Sebagai bagian dari kehidupan rutin atau ritualisasi.

Komunikasi massa mempunyai efek atau pengaruh terhadap reaksi khalayak. Jenis-jenis perubahan atau efek yang terjadi pada diri khalayak komunikasi massa meliputi : perubahan sikap, perasaan, dan perubahan perilaku ; atau dengan istilah lain, perubahan kognitif, afektif, dan konatif.

\section{Komunikasi Pemasaran}

Komunikasi pemasaran memegang peranan yang sangat penting bagi pemasar. Tanpa komunikasi, konsumen maupun masyarakat secara keseluruhan tidak akan mengetahui keberadaan produk di pasar.

Komunikasi pemasaran menurut Sutisna yang dikutip dalam bukunya Perilaku Konsumen dan Komunikasi Pemasaran adalah "merupakan usaha untuk menyampaikan pesan kepada publik terutama konsumen sasaran mengenai keberadaan produk di pasar".

Terjadinya komunikasi pemasaran diawali dengan proses mengirim pesan pemasaran kepada konsumen yang dilakukan oleh sender atau sumber (source) yaitu pemasar. Pemasar menentukan bagaimana pesan itu disusun agar bisa dipahami dan direspon secara positif oleh penerima (konsumen). Ketika pesan diterima, konsumen akan memberikan respon terhadap pesan yang disampaikan baik positif maupun negatif. Pada proses ini konsumen akan memberikan interpretasi atas pesan yang diterima dengan perubahan sikap atau perilaku. Konsumen memberikan respon sesuai dengan apa yang diharapkan pemasar. Apabila dijelaskan dengan bagan maka akan terlihat :

Dalam melakukan kegiatan pemasaran, proses yang penting adalah melakukan kegiatan promosi yang dilaksanakan oleh produsen dalam memasarkan produknya, karena tanpa proses promosi ini kemungkinan terjadinya transaksi ataupun penjualan akan tersendat.

Promosi adalah semua yang dilakukan untuk membantu penjualan produk atau jasa di setiap tempat jaringan penjualan mulai dari bahan-bahan presentasi yang digunakan seorang tenaga penjualan ketika melakukan penawaran hingga siaran 
niaga di televisi atau iklan di surat kabar yang mencoba memikat pelanggan agar memperoleh kesan yang menyenangkan terhadap apa yang diiklankan.

\section{Hakikat dan Pengertian Iklan}

Televisi merupakan salah satu media periklanan, sekarang tumbuh menjadi suatu industri yang berprospek cerah dan pertumbuhannya semakin pesat. Televisi merupakan media elektronik yang memiliki dua unsur yaitu audio dan visual. Dengan gambar dan gerak pesan yang disampaikan dalam sebuah iklan lebih terkesan realistik, karena sifatnya yang visual dan merupakan kombinasi antara warna,suara dan gerakkan sehingga terlihat nyata.

Periklanan menurut George E. Belch dan Michael A. Belch (2001) di buku Rudy Hardjanto adalah segala bentuk komunikasi nonpersonal yang di bayar, mengenai organisasi, produk, jasa atau gagasan. Pengertian dibayar adalah mencerminkan ruang atau waktu di media yang harus di beli untuk menyampaikan sebuah pesan. Sedangkan non personal, berarti media massa seperti televisi, radio atau surat kabar yang menyampaikan pesan kepada sekelompok besar khalayak pada saat yang relatif bersamaan.

Iklan televisi telah menciptakan karakteristiknya sendiri, yaitu menambah daya pengulangan dan kesinambungan pengaruh terhadap sebuah bentuk media iklan. Visualisasi iklan TV merupakan suatu rangkaian gambaran kartun yang dibuat dalam bentuk berupa layar TV atau persegi panjang yang menampilkan alur cerita iklan yang diusulkan, yang disebut sebagai storyboard. Dalam buku Membidik Pasar Indonesia (STP, 2000:537) ada tiga elemen yang menjadi kekuatan iklan iklan televisi dan menjadi acuan bagi kreator iklan yang handal, yakni key words, key sound, dan Ketiga elemen tersebut yaitu;

\section{Key Words (kata - kata kunci)}

Kata - kata diolah dengan sebagus mungkin agar memiliki keajaiban makna dan bergaya bahasa yang mudah dicerna sehingga efektif serta mudah di terima oleh audiencenya. Penggunaan slogan dalam iklan juga penting sehingga iklan tersebut memiliki ciri khas sendiri.

\section{Key Sound}

Dalam iklan televisi perlu juga ditunjang dengan audio yang baik, sehingga kata - kata yang telah dirangkai memilki unsure "ear catching" serta memaparkan secara jelas pesan informasi yang disampaikan dan dapat diterima denganbaik oleh audience.

\section{Key Visual.}

Visual harus disesuaikan dengan naskah iklan, untuk itu visualisasi dalam iklan sebaiknya memilki "eye catching" sehingga dapat mendorong adanya action atau tindakan audience terhadap pesan yang disampaikan.

Konsep kreatif iklan dikatakan sebagai proses reka bentuk pesan yang meliputi kegiatan mempertalikan unsur-unsur iklan ke dalam suatu keseluruhan, dimana tiap-tiap unsur diolah dan kemudian dipersatukan merupakan kunci dari suatu proses kreatif iklan.

Konsep kreatif iklan terdiri dari :

a. Alur cerita, jalan cerita dalam iklan tersebut. 
b. Setting, tempat atau lokasi yang digambarkan dalam suasana cerita iklan tersebut.

c. Tokoh, aktor yang terlibat dalam visualisasi cerita iklan tersebut.

d. Isi pesan, ide atau gagasan yang hendak disampaikan dalam iklan tersebut.

e. Musik, lagu, irama, atau bunyi-bunyian yang terdapat dalam iklan tersebut.

f. Kata kunci atau slogan (magic word). Kata kunci ini berguna agar khalayak dapat mengingat dengan kata-kata yang mengkarakterkan iklan tersebut.

Sedangkan penyajian pesan dalam iklan televisi mempunyai beberapa teknik visual seperti.

- Testimonial. Dalam testimonial secara langsung diiklankan dengan menampilkan gambar (dalam media massa), suara, ucapan - ucapan orang orang terkenal yang secara langsung menganjurkan pemakaian suatu produk tertentu. Iklan seperti ini biasanya melibatkan iklan bisnis profesi. Contohnya menampilkan suara seorang dokter terkenal yang menyampaikan pesan untuk iklan suatu alat kontrasepsi tertentu. Seorang bintang olahraga bulutangkis ditampilkan untuk memberikan keyakinan bahwa ia juga memakai sepatu jenis tertentu yang dapat mengantarkannya menang dalam berbagai pertandingan.

- Spokes person. Teknik ini menampilkan seorang presenter yang berdiri di depan kamera dan menyampaikan naskah pesan secara langsung kepada penoton. Seorang presenter bisa juga sambil mendemonstrasikan produk yang di iklankan. Namun perlu diperhatikan pada pemilihan spoke person, jangan sampai popularitas spoke person tersebut mengalahkan produk yang diiklankan.

- Demonstration. Teknik ini popular untuk beberapa produk, karena televisi dianggap media yang ideal untuk mendemonstrasikan kepada audience bagaimana fungsi produk yang di iklankan tersebut.

- Close Ups. Teknik ini menampilkan bagian produk atau brand yang ditawarkan dengan menggunakan zoom lens (close up). Dengan teknik ini, biasanya menggunakan announcer.

- Story line. Teknik storyline sama halnya untuk membuat sebuah film (terdapat permulaan, pertengahan dan penutup dalam 30 detik).

- Comparisons. Pembandingan satu produk dengan produk yang lain dapat lebih jelas memperlihatkan keunggulan produk kepada audience. Dalam teknik ini, merek pesaing tidak ditampilkan. Namun bisa juga membandingkan dengan menampilkan gaya hidup antara pengguna produk.

- Still Photographs and Artwork. Fotografi atau karya - karya seni termasuk gambar kartun atau karya tulis, dapat dibentuk menjadi sebuah iklan yang menarik. Materi yang diperlukan bisa saja yang sudah ada atau di beli dengan harga tertentu atau bisa saja di foto atau di gambar sesuai dengan keperluan.

- Slice of lice. Ini merupakan teknik kuno dalam drama dimana actor menceritakan ceritayang dapat mempengaruhi orang dengan merek yang di iklankan. Kebanyakan iklan yang berbentuk slice of life (cuplikan kehidupan) diawali dengan sebuah masalah, dan produk atau jasa yang di iklankan menjadi solusi masalah tersebut. 
- Customer Interview. Kebanyakan orang yang tampil dalam iklan adalah aktor yang profesional. Tetapi, Customer Interview melibatkan aktor (talent) yang tidak professional (populer).

- Vignettes and situations. Pengiklan dari minuman ringan, permen, dan lainnya biasanya mendapati teknik ini berguna untuk menciptakan kesenangan dan motivasi. Iklan ini biasanya terdiri dari beberapa bagian / babak yang berdurasi singkat menunjukan konsumen menikmati produk sebagaimana mereka menikmati hidup. Dan biasanya menggunakan jingle atau lagu dengan lirik yang berdasarkan situasi yang terlihat dan kepuasan yang ditawarkan produk.

- Humor. Humor sudah lama merupakan teknik yang popular karena membuat isi iklan lebih menarik. Tetapi bahayanya yaitu aspek humor dari iklan tersebut sering lebih diingat oleh konsumen daripada produk itu sendiri. Dan yang menjadi tantangannya adalah bagaimana membuat humor tersebut menjadi relevan dengan produk.

- Animation. Animasi terdiri dari gambar yang di foto dalam mtion picture film, gambar yang bergerak dari satu frame ke frame lainnya. Animasi bisa digunakan untuk mempermudah demonstrasi produk. Dan biaya animasi tergantung dari gaya animasi yang digunakan. Bila tidak menggunakannya harga produksi iklan bisa di tekan.

- Stop motion. Teknik ini dibuat objek yang difoto dengan posisi dan gerakan yang di stimulasi seperti film kartun.

- Rotoscope. Teknik ini merupakan gabungan dari aksi yang hidup dan animasi yang dibuat terpisah lalu digabungkan.

- Problem Solution. Teknik ini mempunyai tujuan untuk menyelesaikan prospek masalah inti dimana produknya menjual solusi.

- Mood Imagenary. Teknik dapat dikatakan sulit dan mahal. Biasanya gabungan dari beberapa teknik yang tujuan utamanya untuk membuat mood (perasaan situasi tertentu dan citra dari produk uang di iklankan.

- Serials. Teknik ini merupakan iklan yang di buat dari banyak versi, dan setiap versinya berbeda - beda.

- Spilt and Bookend sports. Teknik ini merupakan variasidari iklan serial yang bersambung. Pada serial pertama biasanya di tutup dengan cerita yang belum berakhir. Dan cerita selanjutnya merupakan sambungan dari cerita yang pertama, dan biasanya terdapat jeda.

- Informercials. Adalah iklan yang terlihat seperti sebuah program. Iklan ini menjual dari hal yang terkecil sampai yang terbesar dan biasanya ditayangkan selama 30 menit.

- Combinations. Kebanyakan iklan ini memakai beberapa teknik. Dan merupakan kombinasi logo dari merek produk atau jasa yang di iklankan dengan cerita pada iklan tersebut.

Televisi sebagai media elektronik yang menggunakan siaran, dan merupakan subyek pengontrol sosial yang memiliki jangkauan yang luas. Adapun kelemahan dan kekuatan dari media televisi yaitu :

- Kekuatan televisi adalah efisiensi biaya, dimana televisi mempunyai kemampuan menjangkau khalayak sasaran yang sangat luas; mempunyai 
dampak yang kuat, yaitu dapat menimbulkan tekanan pada sekaligus dua indera : penglihatan dan pendengaran, sehingga khalayak dapat dapat mengkombinasikan antara gerakan, suara dan warna; dan pengaruh yang kuat, dimana televisi mempunyai kemampuan untuk mempengaruhi persepsi khalayak sasaran."

- Kelemahan televisi adalah memerlukan biaya yang sangat besar, dimana untuk kebutuhan produksi dan menyiarkannya secara komersial; khalayak yang tidak selektif, sehingga tidak jarang iklan-iklan yang disiarkan menjangkau pasar yang tidak tepat; dan sering terjadinya kesulitan teknis, karena media ini tidak luwes dalam pengaturan teknis. Iklan-iklan yang telah dibuat tidak dapat diubah begitu saja jadwalnya, apalagi menjelang jam-jam penyiarannya.

Televisi merupakan media yang begitu dekat dengan khalayak. Pada Hakekatnya Periklanan dalam berbagai macam media massa bertujuan untuk menyampaikan suatu pesan dan membujuk suatu kelompok khalayak agar melakukan suatu tindakan yang dikehendaki oleh produsen.

\section{Hakikat Televisi Sebagai Sarana Media Iklan Lifebouy}

Dalam iklan televisi Lifebouy yang saya angkat sebagai bahan kajian penelitian, lifebouy sebagai komunikator menciptakan dua tokoh yaitu Ayah dan anak laki-lakinya. Digambarkan dalam iklan tersebut seorang ayah yang sedang memberi tahu anaknya tentang pentingnya mencuci tangan dengan sabun sebelum beraktivitas. Penokohan sang ayah yang mencoba dengan bernyanyi agar anaknya memiliki kebiasaan mencuci tangan tersebut menjadi daya tarik dalam iklan televisi ini. Pendekatan humor dan riang dilakukan di sini dirasa tepat karena untuk menyuarakan hal-hal serius namun sepele seperti mencuci tangan ini sesuatu yang menghibur dan ringan bisa dijadikan cara yang tepat.

Pesan sosial yaitu pentingnya mencuci tangan dengan sabun sebelum beraktivitas menjadi isi dari iklan televisi ini. Keinginan untuk bisa membangun kebiasaan mencuci tangan sebelum beraktivitas dalam iklan ini lebih terlihat jelas dibandingkan menjual kualitas produk. Iklan ini lebih menyerupai media pembelajaran sosial daripada iklan sebuah produk.

\section{Fungsi dan Tujuan Iklan}

Fungsi utama iklan adalah sebagai medium pemasaran atas suatu produk barang atau jasa. Intinya adalah fungsi periklanan adalah salah satu alat yang memiliki tujuan untuk pemasaran atau salah satu cara untuk memasarkan sesuatu baik itu produk barang atau jasa.

Tujuan Periklanan adalah agar produk barang atau jasa yang dipasarkan dapat lebih mudah dalam menjangkau khalayaknya sebagai target market yang lebih besar. Iklan dipandang sebagai suatu media informasi tentang kemampuan, harga, fungsi produk, maupun atribut lainnya yang berkaitan dengan suatu produk, konsumen sering sekali dihadapkan pada kurangnya informasi yang berkaitan dengan harga maupun kualitas produk yang dibutuhkannya.

Segi positif periklanan juga dapat dikemukakan melalui definisi lain yang mengatakan bahwa : "periklanan merupakan cara menjual melalui penyebaran 
informasi”. Namun tidak sembarang informasi yang perlu dikemukakan, dan tidak semua informasi merupakan iklan.

Berdasarkan medianya, Frank Jefkins mengkategorikan periklanan menjadi dua jenis, yaitu :

1. Above The Line atau Media Lini Atas. Media yang termasuk dalam kategori ini adalah majalah, televisi, radio, dan sinema atau bioskop.

2. Below The Line atau Media Lini Bawah. Media yang termasuk dalam kategori ini adalah direct mail, hanging mobile, $t$-shirt, pameran dan perangkat-perangkat peragaan (display).

\section{Perilaku Konsumen}

Perilaku konsumen merupakan suatu tindakan nyata konsumen yang dipengaruhi oleh faktor-faktor kejiwaan dan faktor luar lainnya yang mengarahkan mereka untuk memilih dan mempergunakan barang/jasa yang diinginkannya.

Seperti yang didefinisikan oleh Schiffman dan Kanuk 2000 (dalam Ristiyanti P dan John J.O.I, 2004 : 9) adalah "proses yang dilalui oleh seseorang dalam mencari, membeli, menggunakan, mengevaluasi, dan bertindak pasca konsumsi produk, jasa maupun ide yang diharapkan bisa memenuhi kebutuhannya". Jadi, dapat dikatakan bahwa perilaku konsumen merupakan studi tentang bagaimana pembuat keputusan, baik individu, kelompok, ataupun organisasi, membuat keputusan-keputusan beli atau melakukan transaksi pembelian suatu produk dan mengkonsumsinya.

Perilaku kosumen adalah suatu proses yang terdiri dari beberapa tahap yaitu:

1. Tahap perolehan (acquisition) : mencari (searching) dan membeli (purchasing)

2. Tahap konsumsi (consumption) : menggunakan (using) dan mengevaluasi (evaluating)

3. Tahap tindakan pasca beli (disposition) : apa yang dilakukan oleh konsumen setelah produk itu digunakan atau dikonsumsi.

Proses ini dapat digambarkan sebagai berikut :

Teori menurut Kerlinger adalah "himpunan konstruk (konsep), definisi dan proporsi yang mengemukakan pandangan sistematis tentang gejala dengan menjabarkan relasi diantara variabel, untuk menjelaskan dan meramalkan gejala tersebut".

Menurut Drs. Mardalis, kerangka teori dimaksudkan untuk memberikan gambaran atau batasan-batasan tentang teori-teori yang dipakai sebagai landasan penelitian yang dilakukan adalah teori mengenai variabel-variabel yang akan diteliti. adalah:

Teori yang digunakan untuk menyelesaikan masalah dalam penelitian ini

Selain itu teori yang juga digunakan dalam penelitian ini adalah SOR, model SOR berasal dari model stimuli respon $(\mathrm{S}-\mathrm{R})$ menurut pendekatan psikologi dimodifikasi oleh De fleur dengan memasukkan unsur organisme, dalam membentuk komunikasi dan pengaruhnya terhadap orang perorangan, istilah yang digunakan yaitu : 


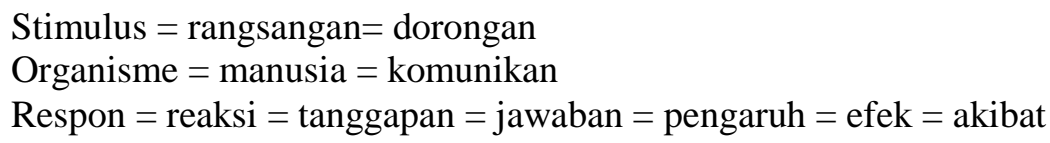

1. Stimulus : isi pernyataan yaitu massage $=$ tayangan iklan televisi lifebouy 5 resep dokter kecil lifebouy.

Dalam penelitian ini stimulus diwakili oleh tayangan iklan (iklan).

2. Organisme : perhatian, pengertian, penerimaan, badan yang hidup yaitu Murid kelas VII SLTPN 240

Yang dimaksud organisme dalam penelitian ini adalah Murid kelas VII SLTPN 240.

3. Respon : pengaruh yang terjadi yaitu efek =perubahan perilaku.

Respon atau efek yang diharapkan dalam penelitian ini yaitu sikap konsumen dalam perubahan perilaku setelah melihat tayangan iklan lifebouy.

Respon atau efek yang diharapkan dalam penelitian ini yaitu sikap konsumen untuk melakukan perubahan perilaku.

"Gambar di atas menunjukkan bahwa perubahan sikap bergantung pada proses yang terjadi pada individu. Stimulus atau pesan yang disampaikan kepada komunikan mungkin diterima atau mungkin ditolak. Setelah komunikan mengerti, lalu komunikan mengolahnya dan menerima, maka terjadilah kesediaan untuk merubah sikap/perilaku."

Jadi menurut teori ini, apabila penonton sebagai calon konsumen ( Pada Murid kelas VII SLTP Suluh menaruh perhatian terhadap tayangan iklan televisi sabun lifebouy 5 resep dokter kecil lifebouy "versi Dik-Doank" dan mengerti pada iklan tersebut lalu mereka bisa mengingat, maka mereka akan melakukan perubahan sikap terhadap iklan tersebut apakah mereka akan mencoba produk tersebut atau walaupun mereka mengerti makna iklan tersebut mereka berhak untuk tidak mencoba ataupun memutuskan untuk membeli.

\section{Teori Belajar Sosial}

Sebagian besar kecenderungan tanggapan dari kita dipelajari bukan hanya semata-mata melalui pengamatan langsung, melainkan dengan mengamati orang lain dan dari perintah-perintah orang lain.

Albert Bandura menyajikan teori perilaku manusia secara umum yang disebut "social learning theory" teori ini menjelaskan bagaimana kita belajar dari pengalaman langsung sepertinya hal nya dari pengamatan dan permodelan. Teori pembelajaran sosial menjelaskan perilaku faktor lingkungan dan faktor kognitif. Teori ini mempertimbangkan unsur penguatan dalam berperilaku dan stimulus sebagai hal penting, tetapi hal itu juga mempertimbangkan pengaruh proses berpikir terhadap pembelajaran pada manusia. Teori pembelajaran sosial secara khusus relevan dengan komunikasi massa karena banyak perilaku yang kita pelajari melalui permodelan (modelling) merupakan pengamatan pertama di media massa.

Unsur-unsur utama dalam analisis Bandura :

- Proses perhatian

Media mempunyai peran penting dalam pembelajaran sosial. Banyak yang kita pelajari dari media massa, khususnya media visual. Langakah pertama 
dalam pembelajaran sosial ialah perhatian terhadap peristiwa tersebut. Menurut Bandura perhatian terhadap suatu peristiwa ditentukan oleh karakteristik peristiwa tersebut. (atau stimuli model) dan oleh karakteristik pengamat. Peluang-peluang untuk mempelajari suatu peristiwa ditingkakatkan dengan pengamatan yang berulang terhadap peristiwa tersebut. Peristiwa-peristiwa akan memperkuat pendirian kita kalau hal itu memenuhi kebutuhan kita, seperti memberikan solusi atas masalah atau bila memberikan hiburan, yang sering dilakukan media.

- Proses pengingatan

Teori pembelajaran sosial menaruh perhatian pada peniruan tertunda(delayed modeling).peniruan tertunda tidak terjadi jika tidak ingat pengamatan yang di observasi.

Menurut Bandura, kita melakukan pola-pola tanggapan (tindakan atau peristiwa yang ditiru) dalam dua sistem (imaginal dan verbal). Tindakan imaginal (visual imagery), berisi gambaran mental dari tidakan ulang diamati dan menyimpan gambaran tadi pada memori kita. Kita juga dapat mengingat peristiwa-peristiwa yang rumit dengan menggunakan simbol melalui kode-kode verbal. Sehingga membuat proses penyimpanan informasi dan penggunaanya menjadi lebih sederhana.

- Proses reproduksi motorik

Menurut Bandura, tindakan yang dilakukan secara terbuka akan melibatkan langkah-langkah berikut ini: organisasi kognisi mengenai tanggapan, inisiasi (tata cara) tanggapan tersebut, monitoring (pemantauan), dan penyaringan berdasarkan umpan balik informatif

- Proses motivasional

Motivasi tergantung pada penguatan. Ada tiga macam penguatan yang dapat memotivasi kita dalam berindak: penguatan eksternal, penguatan karena orang lain, dan penguatan karena diri sendiri.

Penguatan eksternal ialah ganjaran yang diperoleh sesorang yang melakukan tindakan tersebut. Ganjaran ini merupakan faktor eksternal seperti penerimaan sosial, bebas dari hukuman tau mendapat hak-hak istimewa.

Penguatan karena orang lain akan terjadi kalau kita mengamati orang lain yang melakukan tindakan tertentu.

Penguatan karena diri sendiri juga dapat menentukan dilakukan tindakan dari perilaku yang kita pelajari. Kita dapat mendorong penguatan dalam diri kita sendiri terhadap perilaku yang di tujukkan. Kepuasan diri atau damai didalam merupakan salah satu penguatan diri.

Pada dasarnya tahap komunikasi terbagi atas:

a. Tahap Kognitif

Tahap ini meliputi kesadaran khalayak (awarness) akan kehadiran sabun lifebouy, disertai pengetahuan dan pemahaman tentang atribut, karakteristik serta keuntungan dari produk lifebouy (knowledge).

b. Tahap Afektif 
Setelah terbentuk asosiasi merek dengan baik, khalayak dapat menentukan kesukaannya terhadap produk lifebouy(liking), sehingga khalayak sudah dapat memilih suatu merek dibandingkan dengan merek lainnya (preference). Hal ini menghantarkan khalayak kepada suatu keyakinan yang kuat terhadap produk lifebouy (conviction).

c. Tahap Konatif

Keyakinan akan produk lifebouy baru dapat diketahui dengan pasti setelah seseorang melakukan suatu sikap atau tindakan yang dapat disetarakan dengan perubahan pada perilaku (purchase).

\section{Hipotesis Penelitian}

Berdasarkan kerangka konsep dan variabel penelitian yang telah dijabarkan diatas, maka dapat diajukan hipotesa penelitian sebagai berikut :

"Terdapat pengaruh antara tayangan iklan televisi Sabun lifebouy versi Dik-doang dengan perubahan perilaku pada Murid kelas VII SLTP Suluh Jakarta-Selatan."

\section{Hipotesis Statistik}

(H0) : $r_{x y}=$ 0, tidak terdapat Pengaruh tayangan iklan lifebouy dengan perubahan perilaku pada Murid kelas VII SLTP Suluh Jakarta-Selatan.

(Ha) : $r_{x y}=\mathbf{0}$, terdapat Pengaruh tayangan iklan lifebouy dengan dengan perubahan perilaku pada Murid kelas VII SLTP Suluh Jakarta-Selatan.

\section{B. Metode Penelitian}

Penelitian Asosiatif merupakan penelitian yang bertujuan untuk mengetahui hubungan antara dua variabel atau lebih. Pada penelitian ini akan dijelaskan Pengaruh Iklan televisi lifebuoy versi Dik-doang Terhadap perubahan perilaku murid kelas VII SLTP Suluh

\section{Populasi dan sample}

Populasi adalah wilayah generelasi yang terdiri atas objek /subyek yang mempunyai kualitas dan karakteristik tertentu yang ditetapkan oleh penelitian untuk di pelajari dan kemudian ditarik kesimpulannya.

Berdasarkan penelitian yang membahas "Pengaruh iklan televisi lifebuoy versi Dik-doang terhadap perubahan perilaku Murid kelas VII SLTP Suluh Jakarta”, terdiri dari 7 kelas dengan jumlah keseluruhan 275 murid. Populasi penelitian adalah Murid kelas VII SLTP Suluh berjumlah 275 Murid, dan yang pernah melihat tayangan iklan sabun lifebuoy versi Dik-doang pada saat dilakukan pra penelitian berjumlah 128 Murid.

\section{Tabel 3.1}

\section{Populasi geografis}

\begin{tabular}{|c|c|c|c|c|c|c|c|}
\hline Kelas & VII -1 & VII - 2 & VII - 3 & VII - 4 & VII - 5 & VII - 6 & VII - 7 \\
\hline JUMLAH & 39 & 40 & 43 & 38 & 40 & 40 & 35 \\
\hline
\end{tabular}

Jumlah $=275$ Murid 
Tabel 3.2

Populasi geografis yang pernah melihat tayangan iklan lifebuoy "Versi Dik-Doang"

\begin{tabular}{|c|c|c|c|c|c|c|c|}
\hline Kelas & VII -1 & VII - 2 & VII - 3 & VII - 4 & VII - 5 & VII - 6 & VII - 7 \\
\hline JUMLAH & 22 & 18 & 17 & 25 & 21 & 15 & 10 \\
\hline
\end{tabular}

Dengan Jumlah : 128 Murid

Teknik yang digunakan dalam penelitian ini merupakan teknik proposional sampling yang merupakan bagian dari probability sampling, probability sampling adalah teknik sampling (teknik pengambilan sampling) yang memberikan peluang yang sama bagi setiap unsur (anggota) populasi untuk dipilih menjadi anggota sampel.

Menurut Burhan Bungin,S.Sos.,Msi dalam bukunya Metode Penelitian Kuantitatif, "Proposional sampling" adalah teknik sampel yang lebih leluasa penggunaannya, Maksud teknik ini adalah dapat digunakan pada populasi berstrata, populasi area ataupun populasi cluster. Hal yang terpenting dalam penggunaan tekhnik ini adalah penggunaan perwakilan berimbang, karena itulah sebelum peneliti menggunakan tekhnik ini, peneliti harus mengetahui besar kecil unit-unit populasi yang ada. Kemudian dengan pengetahuan ini peneliti mengambil wakil-wakil dari unit-unit populasi yang ada, dengan sistem perwakilan berimbang.

Contoh apabila peneliti, meneliti sebuah murid kelas 3 Smu dan peneliti sudah mengetahui jumlah populasi geografis, peneliti hanya tinggal memilih beberapa perwakilan dari satu kelas melalui daftar nama atau absen lalu di undi untuk di ambil sampel nya.

\section{Teknik Analisis Data}

Teknik yang digunakan analisa kuantitatif berdasarkan presentase menurut skor kumulatif untuk memberikan kadar penelitian data jawaban responden digunakan skala Likert. Skala Likert digunakan untuk mengukur sikap, pendapat, dan persepsi seseorang atau sekelompok orang tentang fenomena sosial. Dalam penelitian fenomena sosial ini telah ditetapkan secara spesifik oleh peneliti, yang selanjutnya disebut sebagai variabel penelitian. (Sugiyono, 2005:107). Dengan skala Likert, maka variabel yang akan diukur dijabarkan menjadi indikator variabel. Kemudian indikator tersebut dijadikan sebagai titik tolak untuk menyusun item-item instrumen yang dapat berupa pernyataan atau pertanyaan. Jawaban setiap item instrumen yang menggunakan skala Likert mempunyai gradasi dari positif sampai sangat negatif. Untuk keperluan analisis kuantitatif, maka jawaban itu dapat diberi skor sebagai berikut:

Selanjutnya data primer yang di peroleh akan di analisis dengan menggunakan metode ukuran central tendency dengan ukuran Mean dan Modus.

Dari tabel-tabel distribusi frekuensi akan dihasilkan Mean, yang merupakan skor/nilai rata-rata yang pengukurannya didasarkan dengan menjumlahkan seluruh hasil pengamatan dibagi dengan jumlah pengamatan, dan Modus untuk memperlihatkan nilai yang paling sering muncul dari hasil frekuensi. Hasil yang diperoleh digunakan untuk menyimpulkan penelitian yang dilakukan 


$$
\begin{aligned}
& \text { Rumus Mean: } \bar{x}=\frac{\sum s i f i}{\sum f i} \\
& \text { Keterangan: } \quad \mathrm{x}=\text { Mean } \\
& \text { si }=\text { Skor ke-i }(5,4,3,2,1) \\
& \text { fi }=\text { Frekuensi ke-i }
\end{aligned}
$$

Perhitungan tersebut didapat dari penggunaan program SPSS (Statistic Progamme for Social Science). Setelah data tersebut diperoleh, kemudian dapat dilihat hubungan antara variabel-variabel terkait melalui koefisien korelasi seperti pada tabel berikut:

Tabel 3.4

Koefisien Korelasi

\begin{tabular}{|c|c|}
\hline Interval Koefisien & Tingkat Hubungan \\
\hline Kurang dari 0.20 & Sangat rendah \\
$0.20-0.40$ & Rendah \\
$0.40-0.70$ & Cukup \\
$0.70-0.90$ & Kuat \\
Lebih dari 0.90 & Sangat kuat \\
\hline
\end{tabular}

Kemudian data diolah dengan program SPSS, lalu diuji dengan perhitungan statistik "Pearson Correlation Product Management" untuk mengukur seberapa besar hubungan antara dua variabel yang diteliti.

\section{Analisis Hasil Penelitian}

Penulis melakukan penelitian SLTP Suluh, Jakarta. Berkaitan dengan judul penelitian pengaruh tayangan iklan televisi Sabun lifebouy versi Dik-doang dengan perubahan perilaku pada murid kelas VII SLTP Suluh Jakarta-Selatan. Dalam Penelitian ini Total populasi dari penelitian ini sebanyak 128 orang, maka dengan metode penarikan sampel diperoleh nilai sampel sebanyak 56 orang, dan hasil penelitian sebagai berikut:

Tabel 4.1

Jenis Kelamin

\begin{tabular}{|ll|l|l|l|l|}
\hline & & Frequency & Percent & Valid Percent & Cumulative Percent \\
\hline Valid & PRIA & 35 & 62.5 & 62.5 & 62.5 \\
& WANITA & 21 & 37.5 & 37.5 & 100.0 \\
& Total & 56 & 100.0 & 100.0 & \\
\hline
\end{tabular}

Dari diagram diatas, diketahui bahwa responden laki-laki lebih banyak daripada responden perempuan, dari total responden sebanyak 56 orang, 35 orang $(62.5 \%)$ adalah berjenis kelamin laki-laki dan 21 orang (37.5\%) adalah perempuan. 
Tabel 4.2

Pengguna Sabun Kesehatan

\begin{tabular}{|ll|r|r|r|r|}
\hline & & Frequency & Percent & Valid Percent & Cumulative Percent \\
\hline Valid & YA & 30 & 53.6 & 53.6 & 53.6 \\
& TIDAK & 26 & 46.4 & 46.4 & 100.0 \\
& Total & 56 & 100.0 & 100.0 & \\
\hline
\end{tabular}

Dari tabel diatas mengenai identitas responden, diketahui bahwa yang memakai sabun kesehatan lebih banyak dari pada yang tidak memakai sabun kesehatan, dari total responden sebanyak 56 orang, $53.6 \%$ adalah pengguna sabun kesehatan dan $46.4 \%$ adalah tidak menggunakan sabun kesehatan.

Tabel 4.3

Berapa Uang jajan anda selama sebulan

\begin{tabular}{|cc|c|c|c|c|}
\hline & & Frequency & Percent & Valid Percent & $\begin{array}{c}\text { Cumulative } \\
\text { Percent }\end{array}$ \\
\hline Valid & $100000-200000$ & 5 & 8.9 & 8.9 & 8.9 \\
& $200000-300000$ & 16 & 28.6 & 28.6 & 37.5 \\
& $>300000$ & 35 & 62.5 & 62.5 & 100.0 \\
& Total & 56 & 100.0 & 100.0 & \\
\hline
\end{tabular}

Dari tabel diatas mengenai identitas responden, di ketahui bahwa lebih banyak responden yang mendaptkan uang jajan selama sebulan lebih dari 300000 yaitu sekitar 35 orang $(62.5 \%)$.

Tabel 4.4

Frekuensi Melihat Tayangan Iklan lifebuoy versi Dik-Doank

\begin{tabular}{|l|l|l|l|l|}
\hline No & Kategori Jawaban & Skor & Frekuensi (f) & Persen (\%) \\
\hline 1 & Sangat setuju & 5 & 3 & 5.4 \\
\hline 2 & Setuju & 4 & 43 & 76.8 \\
\hline 3 & Ragu-ragu & 3 & 10 & 17.9 \\
\hline 4 & Tidak setuju & 2 & 0 & 0 \\
\hline 5 & Sangat tidak setuju & 1 & 0 & 0 \\
\hline & Total & & 56 & 100.0 \\
\hline
\end{tabular}

Mean : 3.88

Dari tabel diatas dapat terlihat bahwa 43 responden atau (76.8\%), menjawab setuju/sering dalam seberapa sering tayangan iklan Lifebuoy versi DikDoank muncul di televisi dalam satu hari, Mean 3.88 artinya rata-rata responden menjawab pada skor 3.88 yang apabila dibulatkan mengarah pada nilai 4 yang 
artinya responden menyatakan setuju. Mode 4 artinya kecenderungan responden menjawab pada skor 4 yang artinya responden menyatakan setuju.

Tabel 4.5

Intensitas Melihat Tayangan Iklan lifebuoy versi Dik-Doank

\begin{tabular}{|l|l|l|l|l|}
\hline No & Kategori Jawaban & Skor & Frekuensi (f) & Persen $(\%)$ \\
\hline 1 & Sangat setuju & 5 & 3 & 5.4 \\
\hline 2 & Setuju & 4 & 43 & 76.8 \\
\hline 3 & Ragu-ragu & 3 & 10 & 17.9 \\
\hline 4 & Tidak setuju & 2 & 0 & 0 \\
\hline 5 & Sangat tidak setuju & 1 & 0 & 0 \\
\hline & Total & & 56 & 100.0 \\
\hline
\end{tabular}

Mean : 3.88

Dari tabel diatas dapat terlihat bahwa 43 responden atau (76.8\%), menjawab setuju/sering dalam melihat muncul nya tayangan iklan lifebuoy versi Dik-Doank dalam satu hari di televisi, Mean 3.88 artinya rata-rata responden menjawab pada skor 3.88 yang apabila dibulatkan mengarah pada nilai 4 yang artinya responden menyatakan setuju. Mode 4 artinya kecenderungan responden menjawab pada skor 4 yang artinya responden menyatakan setuju.

Tabel 4.6

Alur cerita Iklan Lifebouy Versi Dik-Doank Menarik

\begin{tabular}{|l|l|l|l|l|}
\hline No & Kategori Jawaban & Skor & Frekuensi (f) & Persen (\%) \\
\hline 1 & Sangat setuju & 5 & 11 & 19.6 \\
\hline 2 & Setuju & 4 & 35 & 62.5 \\
\hline 3 & Ragu-ragu & 3 & 10 & 17.9 \\
\hline 4 & Tidak setuju & 2 & 0 & 0 \\
\hline 5 & Sangat tidak setuju & 1 & 0 & 0 \\
\hline & Total & & 56 & 100.0 \\
\hline
\end{tabular}

Mean : 4.02

\section{Uji Hipotesis}

Penelitian ini bertujuan untuk mengetahui seberapa besar pengaruh tayangan iklan lifebuoy pada iklan televisi terhadap perubahan perilaku dikalangan murid kelas VII SLTP Suluh Jakarta.

Hipotesa yang diajukan adalah: "Jika terdapat pengaruh tayangan iklan lifebuoy di televisi berkorelasi positif dengan perubahan perilaku dikalangan murid kelas VII SLTP Suluh Jakarta, maka pengaruh tayangan iklan lifebuoy 5 resep dokter versi Dik-Doang pada iklan televisi dinilai besar terhadap Perubahan perilaku dikalangan murid kelas VII SLTP Suluh Jakarta. 
Maka hipotesis statistiknya adalah:

(H0), rxy $\leq 0$, tidak terdapat Pengaruh tayangan iklan lifebouy dengan perubahan perilaku pada Murid kelas VII SLTP Suluh Jakarta -Selatan..

(Ha), rxy $>0$, terdapat Pengaruh tayangan iklan lifebouy dengan dengan perubahan perilaku pada Murid kelas VII SLTP Suluh Jakarta -Selatan. Dalam pengujian hipotesis tersebut, langkah-langkah yang dilakukan adalah sebagai berikut:

Tabel 4.38

Correlations

\begin{tabular}{|l|r|r|}
\hline & $\begin{array}{c}\text { Iklan lifebuoy 5 resep } \\
\text { dokter kecil versi Dik } \\
\text { Doang }\end{array}$ & $\begin{array}{c}\text { Perubahan perilaku } \\
\text { murid kelas VII } \\
\text { SLTPN 240 }\end{array}$ \\
\hline Pearson Correlation & 1 &, $600^{* *}$ \\
Sig. (2-tailed) & 56 &, 000 \\
$\mathrm{~N}$ &, $600^{* *}$ & 56 \\
\hline Pearson Correlation &, 000 & 1 \\
Sig. (2-tailed) & 56 & 56 \\
$\mathrm{~N}$ & & 56 \\
\hline
\end{tabular}

** Correlation is significant at the 0.01 level

Hasil analisis dalam tabel dapat diinterpretasikan sebagai berikut :

1. Terdapat korelasi hubungan antara tayangan iklan lifebuoy versi Dik Doang di televisi terhadap perubahan perilaku murid kelas VII SLTP Suluh Jakarta, dimana nilai koefisien korelasi ( $\mathrm{r}$ ) di dapat sebesar 0,600. Berdasarkan analisis tersebut dapat disimpulkan bahwa pengaruh iklan lifebuoy versi Dik-Doang ( X ) terhadappPerubahan perilaku murid kelas VII SLTP Suluh Jakarta ( Y ) adalah kuat. Dengan demikian terdapat pengaruh yang kuat dan positif antara variabel $\mathrm{X}$ dan variabel $\mathrm{Y}$.

2. Karena koefesien korelasinya bernilai positif, maka dapat ditentukan arah hubungan adalah positif. Hal ini dapat diartikan bahwa semakin baik suatu iklan maka Perubahan perilaku terhadap pesan yang disampaikan produk dari iklan tersebut akan semakin tinggi.

3. Hasil perhitungan memperlihatkan bahwa nilai peluangnya $0,000<0,01$. Hal ini menunjukkan bahwa hubungan antara variabel iklan lifebuoy versi Dik-Doang dengan variabel perubahan perilaku murid kelas VII SLTP Suluh Jakarta adalah hubungan yang signifikan (**). Dengan demikian Ho : $0(\mathrm{rxy}=0)$ yang menyatakan Tidak terdapat pengaruh antara iklan lifebuoy versi Dik-Doang di televisi terhadap perubahan perilaku murid kelas VII SLTP Suluh Jakarta, ditolak. Sedangkan Ha : >0 (rxy >0) yang menyatakan terdapat pengaruh antara iklan lifebuoy versi Dik-Doang di televisi terhadap perubahan perilaku murid kelas VII SLTP Suluh Jakarta tersebut, dapat diterima. 


\section{E. Analisis Regresi linier sederhana}

Analisis regresi linear sederhana dipergunakan untuk mengetahui pengaruh antara satu buah variabel bebas terhadap satu buah variabel terikat. Persamaan umumnya adalah:

$$
\hat{\mathbf{Y}}=\boldsymbol{\alpha}+\mathbf{b} \mathbf{X}
$$

Dengan $\mathrm{Y}$ adalah variabel terikat dan $\mathrm{X}$ adalah variabel bebas. Koefisien a adalah konstanta (intercept) yang merupakan titik potong antara garis regresi dengan sumbu Y pada koordinat kartesius.

Dalam penelitian ini penulis menggunakan persamaan regresi linier sederhana untuk mengetahui pengaruh variabel bebas terhadap variabel terikat dengan bantuan program SPSS.

Tabel. 4.39

Coefficients $^{\mathbf{a}}$

\begin{tabular}{|l|l|r|r|}
\hline Model & & Unstandardized & \multicolumn{1}{|c|}{ Coefficients } \\
\hline 1 & \multicolumn{1}{|c|}{ B } & Std.Error \\
\hline & $\begin{array}{l}\text { Iklan televisi lifebuoy 5 } \\
\text { resep dokter kecil versi } \\
\text { Dik-Doang }\end{array}$ & 16,314 &, 053 \\
\hline
\end{tabular}

Interpretasi tabel persamaan regresi :

$$
\hat{Y}=16,314+0.301 X
$$

Berdasarkan persamaan tersebut dapat diinterpretasikan bahwa apabila variabel $(\mathrm{X}=0)$ maka variabel $\mathrm{Y}=16.314$ dan setiap kenaikan satu poin $\mathrm{X}$ akan diikuti oleh kenaikan sebesar 0.301 (30.1\%). Dengan demikian setiap kenaikan skor pada variabel tayangan iklan lifebuoy Versi Dik-Doang di televisi ( X ) sebesar 1 unit akan diikuti oleh kenaikan skor variabel perubahan perilaku murid kelas VII SLTP Suluh Jakarta di Jakarta Selatan( Y ) sebesar 0.301 unit pada arah positif dengan konstanta sebesar 16.314.

Persamaan ini juga dapat digunakan untuk memprediksi perubahanperubahan yang terjadi dalam variabel perubahan perilaku murid kelas VII SLTP Suluh Jakarta Selatan ( Y ) ketika variabel tayangan lifebuoy Versi Dik-Doang di televisi ( $\mathrm{X}$ ) berubah.

\section{Uji Kontribusi}

Sedangkan untuk mengetahui sejauh mana kontribusi pengaruh tayangan iklan lifebuoy Versi Dik-Doang di televisi dalam mempengaruhi perubahan perilaku murid kelas VII SLTP Suluh Jakarta Selatan dapat dilihat pada tabel berikut: 
Tabel 4.40

Model Summary

\begin{tabular}{|l|r|r|r|rr|}
\hline Model & $\mathrm{R}$ & \multicolumn{1}{|c|}{ R Square } & Adjusted R Square & \multicolumn{2}{|c|}{$\begin{array}{c}\text { Std. Error of the } \\
\text { Estimate }\end{array}$} \\
\hline 1 & $.600^{\mathrm{a}}$ & .525 & .275 & .421 \\
\hline
\end{tabular}

a. Predictors: (Constant), Tayangan iklan lifebuoy versi Dik-Doank

Perhitungan didapatkan kontribusinya ( $\mathrm{r}^{2}$ ) sebesar 0.525 ( $52.5 \%$ ), artinya tayangan iklan lifebuoy versi Dik-Doank di televisi mempunyai kontribusi sebesar $52.5 \%$ terhadap perubahan perilaku pada Murid kelas VII SLTP Suluh JakartaSelatan, sedangkan sisanya sebesar $47.5 \%$ dipengaruhi oleh faktor lain di luar tayangan iklan televisi produk sabun Lifebuoy versi Dik-Doank.

Perubahan perilaku murid kelas VII SLTP Suluh Jakarta yang telah berpengaruh masih dapat ditingkatkan bila adanya peningkatan dalam hal Tayangan iklan lifebuoy di televisi. Besarnya perubahan perilaku SLTP Suluh dari setiap adanya peningkatan pada unsur-unsur tayngan iklan lifebuoy dengan menggunakan persamaan regresi linier sederhana dapat dilihat pada tabel di bawah ini.

\section{F. Hasil Pembahasan}

Dari penelitian yang dilakukan pada murid SLTP Suluh Jakarta mengenai seberapa kuat pengaruh iklan lifebuoy 5 resep dokter kecil versi Dik-Doang di televisi terhadap perubahan perilaku murid kelas VII SLTP Suluh Jakarta, diukur dari beberapa indikator antara lain alur cerita, isi pesan, lokasi/setting, model, slogan, musik/suara dan kata kunci.

Dengan adanya iklan lifebuoy 5 resep dokter kecil versi Dik-Doang di televisi dapat memberi pengaruh pada perubahan perilaku murid kelas VII SLTP Suluh Jakarta. Karena apabila iklan tersebut memenuhi karakteristik iklan yang ada, maka tentu saja akan menumbuhkan perubahan perilaku murid kelas VII SLTP Suluh terhadap produk yang diiklankan. Perubahan perilaku murid kelas SLTP Suluh terhadap iklan lifebuoy 5 resep dokter kecil versi Dik-Doang di televisi dapat diukur dari perhatian murid kelas VII SLTP Suluh Jakarta terhadap iklan lifebuoy 5 resep dokter kecil versi Dik-Doang di televisi, pengertian tentang iklan lifebuoy 5 resep dokter kecil versi Dik-Doang di televisi, serta apakah produk tersebut dapat mempengaruhi perubahan perilaku dalam benak/pikiran konsumen.

Indikator variabel pengaruh iklan lifebuoy 5 resep dokter kecil versi DikDoang di televisi (X) dan perubahan perilaku murid kelas VII SLTP Suluh Jakarta (Y) tersebut telah terbukti empiris di lapangan, hal ini juga didukung dari teori-teori yang dikaitkan dalam penelitian ini, yakni Teori S-O-R (Stimulus-OrganismRespons) yang mengatakan bahwa stimulus/pesan yang disampaikan pada komunikan dapat diterima atau ditolak. Komunikasi akan berlangsung jika ada perhatian dari komunikan dan kemudian diteruskan pada proses berikutnya dimana komunikan akan menjadi mengerti terhadap pesan yang disampaikan. Setelah 
komunikan mengolahnya maka pada saat itu terdapat kesediaan untuk merubah sikap atau disebut juga respon.

Dalam penelitian ini ingin diketahui seberapa perubahan perilaku murid kelas VII SLTP Suluh Jakarta, terhadap merek lifebuoy melalui iklan lifebuoy 5 resep dokter kecil versi Dik-Doang di televisi. Karena itu isi pesan harus menarik serta jelas dan informasi yang disampaikan betul-betul sesuai dengan kebutuhan agar efektif dan diterima oleh responden.

Dan apabila dikaitkan dengan "social learning theory", murid kelas VII SLTP Suluh Jakarta yang diterpa oleh pesan yang ada dalam iklan lifebuoy 5 resep dokter kecil versi Dik-Doang di televisi, memberi kemungkinan, melalui proses pengalaman atau belajar secara melihat langsung, dan pilihan pada salah satunya sebagian ditentukan oleh karakteristik dari iklan tersebut. Isi pesan yang disampaikan dari iklan tersebut mempengaruhi respon yang akan terjadi pada murid kelas VII SLTP Suluh Jakarta, sebab setiap orang hanya akan mengingat suatu iklan yang paling berkesan sesuai dengan kebutuhan masing-masing individu. Apabila isi pesan dari suatu iklan tidak dapat mewakili apa yang diinginkan konsumen, maka iklan tersebut tidak akan dipilih sebagai iklan yang berkesan meskipun bersifat paralel. Dalam penelitian ini, sikap yang diinginkan adalah kesadaran merek murid kelas VII SLTP Suluh tehadap merek lifebuoy.

Sedangkan peran model Hierarchy of Effect adalah saat murid kelas VII SLTP Suluh Jakarta menonton tayangan iklan lifebuoy 5 resep dokter kecil versi Dik-Doang di televisi, maka secara tidak langsung akan terbentuk pola model Hierarchy of Effect di benak mereka. Bila hal tersebut telah terjadi maka diharapkan murid kelas VII SLTP Suluh Jakarta, responden harus menyadari kehadiran suatu produk di pasaran, setelah responden menyadari keberadaan produk, namun tidak mengetahui lebih tentang informasi soal manfaat dan kualitas produk, oleh sebab itu responden akan mencari tahu tentang manfaat dan kualitas produk, jika responden sudah mengetahui tenatang produk, maka akan dilihat bagaimana perasaan mereka jika tidak menyukai produk, setelah itu khalayak mungkin menyukai produk, namun tidak akan mengutamakannya dari produk yang digunakan sebelumnya, khalayak mungkin lebih menyukai produk tertentu namun tidak berniat untuk membelinya dan masih mencari tahu informasi lebih, sebagian dari khalayak mungkin sudah memiliki keputusan, namun belum melakukan tindakan yang disampaikan, mereka mungkin menunggu lebih banyak informasi atau berencana membelinya dan melakukan apa yang disampaikan pada pesan iklan lifebuoy versi "Dik-Doang" di televisi terhadap perubahan perilaku murid SLTP Suluh sebesar 52,5\% sedangkan $47,5 \%$ lainnya dipengaruhi oleh faktor-faktor lain di luar penelitian.

\section{G. Simpulan}

Berdasarkan hasil penelitian pengaruh tayangan iklan lifebuoy 5 resep dokter kecil versi Dik-Doang terhadap perubahan perilaku Jakarta dikalangan murid kelas VII SLTP Suluh yang dilakukan peneliti, maka dapat diambil kesimpulan sebagai berikut :

Tanggapan murid kelas VII SLTP Suluh Jakarta-Selatan terhadap tayangan iklan lifebuoy versi Dik-Doang di televisi, di nilai baik dalam mempengaruhi perubahan perilaku mereka. Hal ini dapat dilihat dari nilai rata-rata mean sebesar 
4.05 (baik) atau dapat dikatakan mayoritas responden cenderung setuju terhadap setiap pertanyaan yang di ajukan dalam kuesioner.

Perubahan perilaku responden terhadap produk lifebuoy dinilai baik, hal ini dapat dilihat dari hasil uji lapangan yang memperoleh temuan penelitian rata-rata mean sebesar 4.07 (baik) atau dapat dikatakan mayoritas responden cenderung setuju terhadap setiap pertanyaan yang diajukan dalam kuesioner.

Terdapat hubungan yang positif dan signifikan antara pengaruh tayangan iklan lifebuoy versi Dik-Doang di televisi dengan perubahan perilaku murid kelas VII SLTP Suluh Jakarta-Selatan, dilihat dari tabel perolehan koifisien korelasi $\mathrm{r}$ hitung sebesar 0.600 yang berada pada batas lebih besar dari $0\left(r_{x y}>0\right)$ artinya, arah hubungan yang terjadi adalah positif, maka $\mathrm{HO}$ ditolak dan $\mathrm{Ha}$ diterima. Hal ini berarti tayangan iklan lifebuoy versi Dik-Doang di televisi berpengaruh terhadap perubahan perilaku murid kelas VII SLTP Suluh Jakarta-Selatan.

\section{Daftar Pustaka}

Bilson Simamora, Riset Pemasaran, Jakarta PT Gramedia, Pustaka Utama, 1994.

Bungin, Burhan, S.Sos., M.S, Metode Penelitian Kuantitatif, Prenada Media Group. 2005

Dendi Sudiana, Komunikasi Periklanan Cetak, Bandung, Remaja Karya 2006.

Dennis McQuail, Teori Komunikasi Massa edisi 7, Jakarta, Erlangga.

Djuarsa Sendjaja, Sasa, Teori Komunikasi, Jakarta, Pusat Penelitian Universitas Terbuka 2002.

Effendy, Onong Uchjana, Ilmu Komunikasi Teori dan Praktek, Bandung, Rosda karya, 2000.

Effendy, Onong Uchjana. Ilmu, Teori dan Filsafat Komunikasi. Bandung: Citra bakti.

Effendy, Onong, Uchjana, Ilmu Teori dan filsafat komunikasi, Bandung, Remaja Rosdakarya, 2001

Fred E. Hahn, dan Keneth G Mangun, Beriklan dan Berpromosi Sendiri, Edisi Kedua, Jakarta Grasindo, 1999.

Harjanto Rudy, prinsip-prinsip periklanan. ITKP, 2009

http://cheatonunpad.wordpress.com/2010/01/11/cuci-tangan-cara-mudah-hidup$\underline{\text { sehat }}$

http://skripsimahasiswa.blogspot.com/2009/12/analisa-regresi-dan-korelasi-1.html 
Jalaluddin Rakhmat, Psikologi Komunikasi, Bandung, Remaja Rosdakarya, 1999.

Jefkins Frank, Periklanan, edisi ketiga, Jakarta, Erlangga, 1994.

Jenkins Fank, Periklanan, Jakarta, Erlangga, 1995.

Kotler Philip, Kevin, Lane , Keller, manajemen pemasaran. 2004

Kotler Philip, Marketing Pemasaran, the millenium editon, Upper Saddle RiverNew jersey: Prentice Hall Inc, 2000.

Madjadikara, S, Agus. Bagaimana biro iklan memproduksi iklan, Gramedia Pustaka Utama, Jakarta: 2004.

Mar"at”, sikap manusia perubahan serta pengukurannya,Grafindo, Jakarta. 1995.

Mardalis, Drs. Metode Penelitian, Bumi Aksara, Jakarta, 1999.

Ristiyanti P dan John J.O.I, Perilaku Konsumen, Andi Yogyakarta, Yogyakarta, 2004.

Russell,Thomas.J. Lane,Ronald.W.Kleppner's Advertising Procedure.Prentice Hall International Editions,Printed in the USA. 2005.

Sebdaya, S Dhuarsa, Pengantar Komunikasi. Universitas Terbuka, Jakarta, 1999.

Sendjaja, S. Djuarsa, Teori Komunikasi, Universitas Terbuka, Jakarta, 1993.

Sendjaja, S.Djuarsa, Teori Komunikasi, Universitas Terbuka, Jakarta, 2001.

Sigit Santosa, Advertising Guide Book, Gramedia Pustaka Utama, Jakarta, 2002.

Sugiono, Metode Penelitian Admistrasi, Alfabet, 2005.

Sugiyono, Metode Penelitian Bisnis, Prenada Media Group, 2005.

Suprapto, Tommy. Pengantar teori dan management Komunikasi. Medpress.

Sutisna, Perilaku Konsumen dan Komunikasi Pemasaran, PT. Remaja Rosdakarya, Bandung, 2003.

Suyanto. M. Marketing strategy Top Brand Indonesia. Edisi 1, CV. Andi Offeset. Yogyakarta.

Tim pengembang ilmu pendikdikan FIP-UPI, Ilmu dan aplikasi pendidikan, Grasindo, 2007. 
Urpni Lia Cristina, Sujianto Untung, Indrawati Tatik. Komunikasi kebidanan. Jakarta:Kedokteran EGC.

Werner J. Severin dan James W. Tankard. Communication Theorsies: Origin. Method and Uses. New York: Hasting S. Horse. 2007.

Winarso Puji Heru, Siologi Komunikasi Massa:Prestasi Pustaka, 2007. 